\title{
Reproductive biology of the musky octopus Eledone moschata (Cephalopoda: Octopodidae) in the eastern Mediterranean, Egypt
}

\author{
Rafik Riad $^{1}$ and Raouf Kilada ${ }^{2}$
}

1- National Institute of Oceanography and Fisheries, Alexandria, Egypt. 2- Department of Marine Science, Suez Canal University, Ismailia, Egypt. rafik_riad67@yahoo.com

\section{ABSTRACT}

The current study was designed to address the lack of information regarding the reproduction biology of the musky octopus, Eledone moschata, in the Mediterranean Sea. The work presents the first detailed study of seasonal variation in sexual maturity and age determination using length-frequency analysis. The lengthfrequency analysis in both male and female samples revealed 2 modes that are assumed to be 2 years classes. Eggs number per ovary weight (g) showed a significant differences among seasons $(\mathrm{P}=0.001)$, with peak fecundity occurring during the winter followed by a progressive decline in spring through fall. The GSI values also showed similar results where the index value was higher in winter and then declined in the following seasons. This indicates that the spawning season of the musky octopus may occur in the summer and may extend to the fall of the same year. The musky octopus is dioecious. The male were found to reach sexual maturity earlier than the female tissues. The 50\% sexual maturity level was reached at $7.2 \mathrm{~cm}$ CL for males and $7.4 \mathrm{~cm}$ CL mm for females.

Key words: Musky octopus, Eledone moschata, reproduction biology, sexual maturity, length frequency.

\section{INTRODUCTION}

Declining catches in many traditional fisheries have led to increased efforts to develop fisheries for non-traditional species, especially invertebrates such as the cephalopods (Ozyurt et al., 2006). Over the past two decades, several cephalopod species have become important for the world-wide fisheries, as targets of small scale coastal fisheries and/or as bycatch in multispecies fisheries for demersal fish (FAO, 2011). In 2008, about 2.2 million tons of various species were reported to be the world cephalopod catch (FAO, 2011). Among the commercial cephalopods species is the musky octopus Eledone moschata. This species is caught mainly as bycatch of bottom trawl fisheries (Soro and Piccinetti-Manfrin, 1989; Belcari and Sbrana, 1999; Belcari et al., 2002; Krstulovic Sifner and Vrgoc, 2009). Commercial fisheries for the species occur primarily off Japan, Africa and in Mediterranean Sea (Hatanaka, 1979; Guerra, 1981).

The distribution of the musky octopus, Eledone moschata extends throughout the entire Mediterranean and the Gulf of Cadiz in the eastern Atlantic (Roper et al., 1984; Lefkaditou et al., 1998, 2001; Pipitone et al., 2000; Quetglas et al., 2000; Salman et al., 2000; Belcari et al., 2002) and in the Adriatic (Piccinetti and Jukic, 1988; Casali et al., 1998; Krstulovic Sifner et al., 2004, 2005). It is widely distributed on the continental shelf, and can reach as deep as $100 \mathrm{~m}$ but it is most abundant at depth between 15 and $70 \mathrm{~m}$ (Mangold-Wirz, 1963). The reproductive biology of different cephalopod species has been the subject of many research investigations during the last 30 years, for example, Loligo forbesi (Gabr and Riad, 2008); Octopus 
pallidus (Leporati et al., 2008); Octopus maya (Poveda et al., 2009); Uroteuthis duvauceli (Kilada and Riad, 2010). Nevertheless, the reproductive biology of the musky octopus was investigated in the Aegean Sea area in Turkey (Akyol et al., 2007) yet little is known about its seasonal variation of sexual maturity in the eastern Mediterranean. Information on maturation and spawning of this species will contribute to knowledge of its general biology, population dynamics, and management of the stocks.

The current study was designed to address the lack of information regarding the reproduction biology of the musky octopus in the Mediterranean Sea. The work presents the first detailed study of seasonal variation in sexual maturity and age determination using length-frequency analysis. The study also documents the spawning season and length at first maturity of the species under investigation in the area.

\section{MATERIAL AND METHODS}

A total of 279 octopus Eledone moschata specimens were seasonally collected for the current study during the period between January 2011 and December 2011 from commercial trawlers operating off Alexandria waters. All animals were kept frozen until they were processed. After thawing in room temperature, the dorsal mantle length (ML) was measured to the nearest $0.1 \mathrm{~cm}$ and the total body weight (TWt) was recorded to the nearest gram.

Pooled data of both sexes was used to demonstrate the relationship between the dorsal mantle length (ML) and total weight (TWt) using the following equation: $T W t$ $=a M L^{b}$. Parameters $a$ and $b$ were calculated using ordinary least squares regressions. Although there was a little difference in the relationship of the sexes, the pooled data was used here due to the absence of a statistical difference between the slopes of males and females curves (ANCOVA; $P=0.3$ ). The slopes ( $b$ coefficient) for the males and females were 2.68 and 2.77, respectively. Prior to analysis, normality and homogeneity of variances were verified by Kolmogorov-Smirnov and Bartlett tests, respectively. All statistical analyses were carried out using SYSTAT 2009 for Windows (version 13; SPSS Inc., Chicago, IL). A t-test was used to determine whether the slope coefficient $b$ (i.e., allometric scaling factor) departed significantly from 3 (= isometry). The allometry is negative when $b$ is less than 3 and is positive when $b$ is greater than 3 (Teissier, 1948). Moreover, the sex ratio (male: female) was estimated in each season.

Length-frequency data for each sex were prepared using $0.5 \mathrm{~cm}$ (CL)-intervals. These data were divided into cohorts that are assumed to represent separate age classes by applying the method of Bhattacharya (1967) using the fish stock assessment tool FiSAT II (Gayanilo et al., 2005). The method estimates the mean length and standard error at each year class.

For each individual, sex was determined by checking the presence of the right arm III hectocotylized in males (modified arm) typical for males (Roper et al., 1984). To determine the fecundity, mature ovaries were placed in a jar containing tap water so as to get over egg adherence and make them easily freed apart. The total number of eggs was estimated from the average egg number in three replicates of 0.2 g-samples, after weighing all eggs in the ovary. Counting was carried out through a dissecting microscope. The number of eggs in each individual was then scaled to the total ovary weight. Add to that, the mean number of eggs per ovary weight (g) was calculated for 
every season to investigate the variation by time and to determine whether the variation is associated with the spawning season or not.

The Gonado-Somatic Index (GSI) for both sexes was calculated (Pierce et al., 1994) in each season as follows:

$$
\text { GSI=100xGWt/ (TWt-GWt) }
$$

Where GWt is the gonad weight (g) and TWt is the total body weight (g).

Besides GSI, 1 of 3 maturity stages was assigned to the specimen collected in different seasons (Mangold, 1983; Whitaker et al., 1991). In males, the stages were determined based on two criteria: 1) the presence or absence of spermatophores in the Needham's sac; and 2) the amount of spermatophores in the Needham s sac. The 3 maturity stages are immature where there are no spermatophores in the Needham's sac; mature where the spermatophores are present in the Needham's sac; and spent where very few spermatophores were present in the Needham's sac.

On the other hand, the female maturity stages were determined based on the colour and the state of female ovary. The same three maturity stages are immature, where the ovaries are small and white, and there are no eggs in the ovisac; mature, where the ovaries are large with eggs loose in the ovisac; and spent where the ovaries are flaccid with reddish colour.

To estimate the minimum size at sexual maturity, a sample of 156 females and 126 males were used. The size range was between 4.4 and $11.2 \mathrm{~cm}$ for females and 4.6 and $12.6 \mathrm{~cm}$ for males. The samples were classified into the three maturity stages mentioned above. The proportion of mature individuals was plotted against size aggregated into 5-cm intervals. A logistic curve (McCullagh and Nelder, 1989) was fit to the data by maximum likelihood using the SYSTAT package. The logistic curve is:

$$
\mathrm{P}=\mathrm{e}^{\left(-a+\left(b^{*} \mathrm{~L}\right)\right)} /\left(1+\mathrm{e}^{\left(-a+\left(b^{*} \mathrm{~L}\right)\right)}\right)
$$

where $\mathrm{P}$ is the proportion of mature individuals in the sample, $\mathrm{L}$ is the mantle length (mm), $a$ and $b$ are the model parameters. The mantle length corresponding to 50\% mature individuals was calculated as: $\mathrm{L}_{50}=-a / b$. (Bakhayokho, 1983).

\section{RESULTS}

\section{Length-Weight relationship and sex ratio:}

The size range and number of animals that were collected in each season are recorded in Table 1. Sex ratio estimation revealed that both sexes are present in almost equal ratios in the four seasons. The growth in total weight in reference to the mantle length (Fig.1) was isometric ( $b=2.681,95 \% \mathrm{CI}=2.80-3.0)$.

Table 1: Number, mantle length range $(\mathrm{cm})$, mean mantle length, and SE of mantle length for Eledone moschata Lamarck, 1798.

\begin{tabular}{lccccccccccc}
\hline \multicolumn{1}{c}{ Season } & \multicolumn{3}{c}{ Male } & \multicolumn{9}{c}{ Female } & Sex Ratio (M:F) \\
& N & Min. & Max. & Mean & SE & N & Min. & Max. & Mean & SE & \\
\hline Winter & 30 & 6.0 & 10.9 & 8.6 & 0.2 & 37 & 6.2 & 11.1 & 8.3 & 0.2 & $1: 1.2$ \\
& & & & & & & & & & & \\
Spring & 30 & 5.7 & 12.6 & 9.6 & 0.3 & 37 & 5.6 & 11.2 & 8.6 & 0.3 & $1: 1.2$ \\
Summer & 51 & 4.6 & 12.4 & 7.6 & 0.2 & 39 & 5.1 & 11.0 & 7.1 & 0.2 & $1.3: 1$ \\
Fall & 15 & 5.5 & 8.2 & 7.4 & 0.2 & 40 & 4.4 & 9.3 & 7.3 & 0.2 & $1: 2.7$ \\
\hline
\end{tabular}

N, number; Min., minimum; Max., maximum; SE, standard error, M, male; F, female 


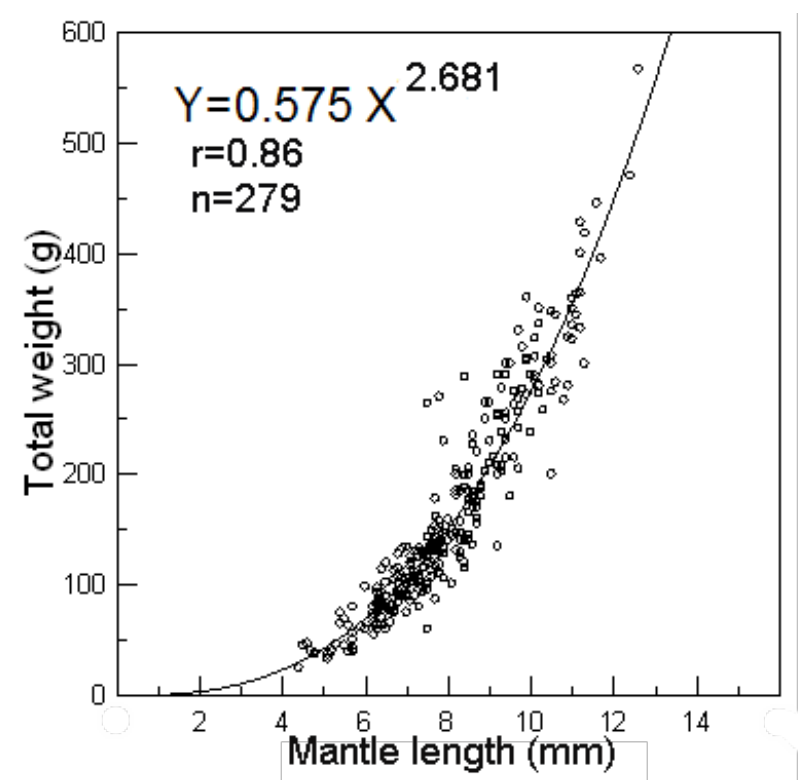

Fig. 1: Eledone moschata Lamarck, 1798, relationship of mantle length to total weight for pooled data of different sexes in eastern Mediterranean.

\section{Length-Frequency analysis:}

The modal analysis conducted by FISAT revealed 2 modes in both male and female samples (Fig. 2). The mean of the first mode was larger in males (8.3 \pm 1.1$)$ than in females $(7.9 \pm 0.6)$. The same trend was observed in the second mode, in which the males had a larger mean $(11.4 \pm 0.7)$ than the females $(10.3 \pm 0.6)$.
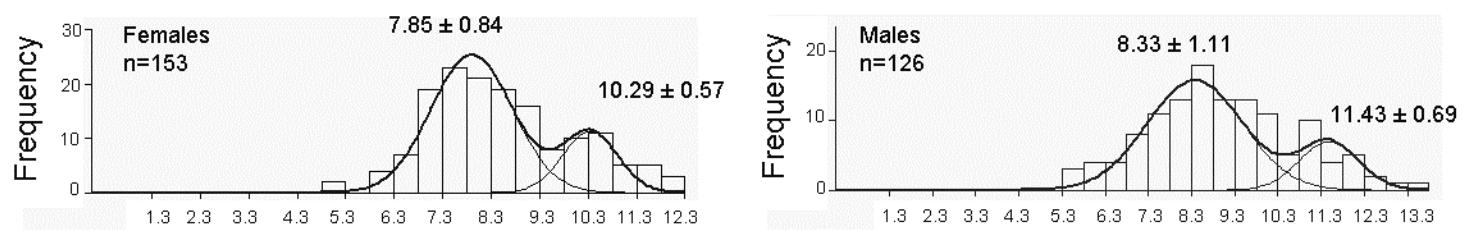

Mantle length $(\mathrm{cm})$

Fig. 2: Eledone moschata Lamarck, 1798, length-frequency distribution of males and females showing the mean length of each mode \pm SD.

\section{Fecundity:}

Estimates of the number of eggs in the ovaries of female Eledone moschata ranged between 430 and 2600. Fecundity was independent of both ovary weight ( $\mathrm{r}=$ $0.2, P>0.1)$ and body weight $(\mathrm{r}=0.1, \mathrm{P}>0.2)$. Meanwhile, the number of eggs per gram of ovary showed a logarithmic decline with increasing ovary weight (Fig. 3), and there was a significant difference in this value between the largest and smallest ovaries ( $\mathrm{r}=0.9, \mathrm{P}=0.03$ ).

Eggs number per ovary weight (g) showed a significant differences among seasons $(\mathrm{P}=0.001)$, with peak fecundity occurring during the winter followed by a progressive decline in the spring to the fall (Fig. 4).

\section{Gonado-Somatic Index (GSI):}

To determine the spawning season, Gonado-Somatic Index (GSI) was estimated (Fig. 5). The GSI illustrated an annual cycle for both sexes. The GSI in the females showed a clear increase during winter and then showed a decline between spring and summer seasons. The minimum values for the GSI were observed in summer before it 
increases in the fall. For males, the GSI was low during winter and then it showed an increase in spring and summer.

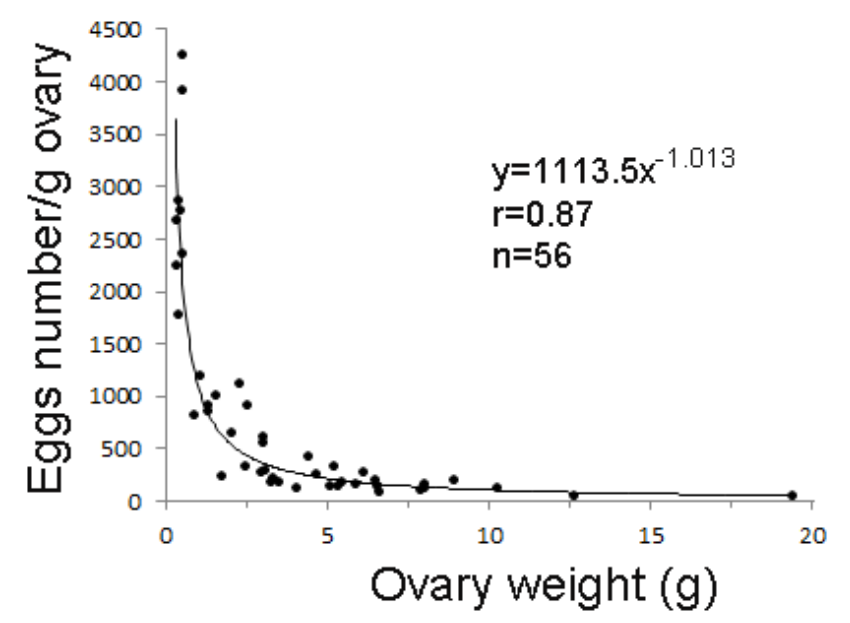

Fig. 3: Eledone moschata Lamarck, 1798, relationship between number of eggs per gram ovary and the total ovary weight.

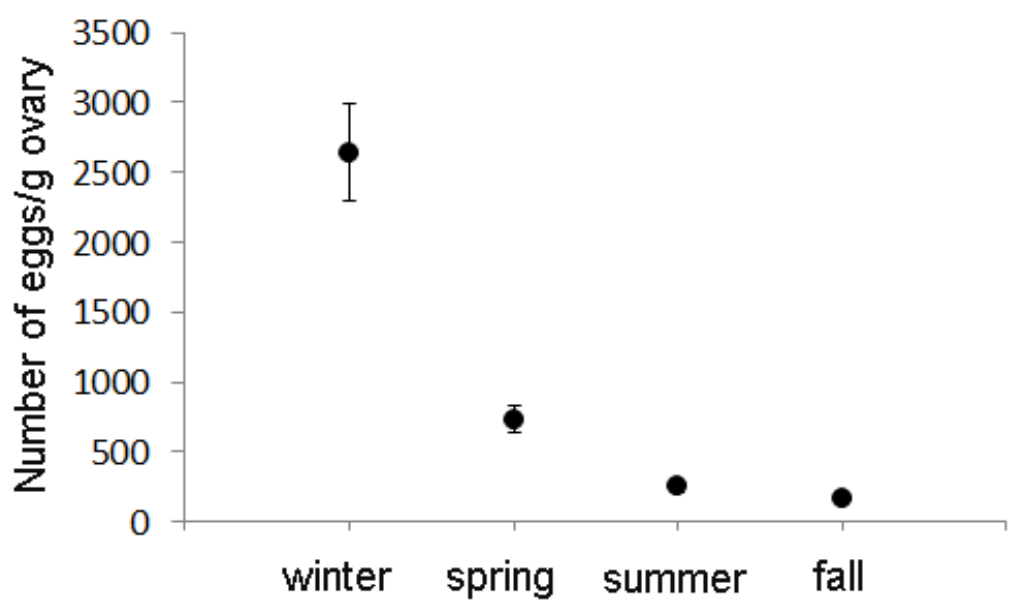

Fig. 4: Eledone moschata Lamarck, 1798, eggs number per gram ovary for in different seasons in eastern Mediterranean.

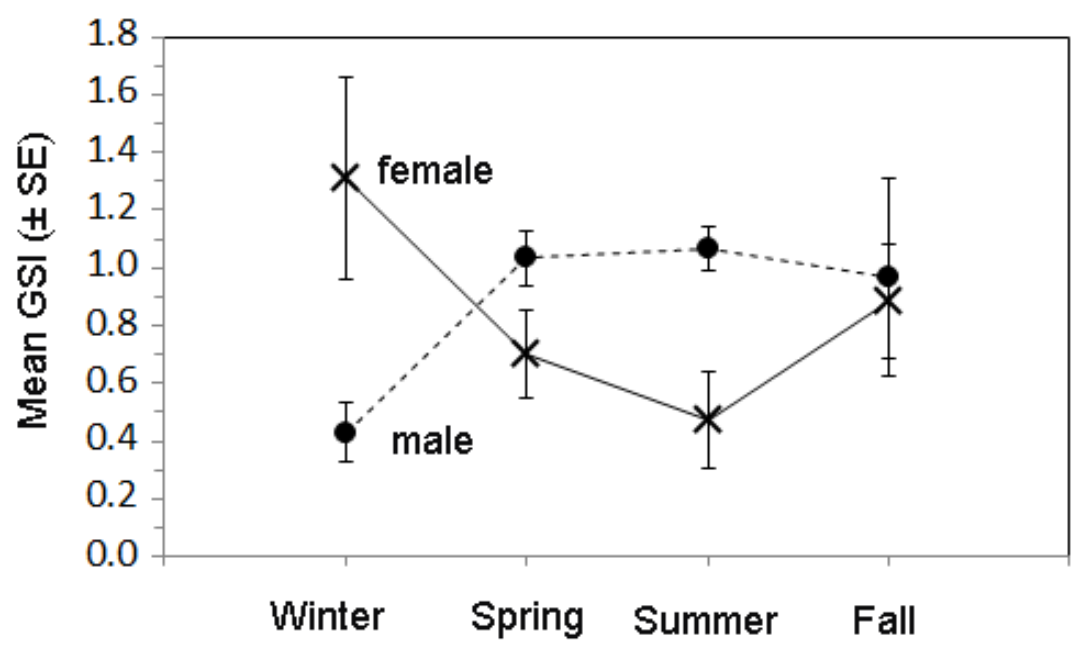

Fig. 5: Eledone moschata Lamarck, 1798, variation in seasonal means of Gonado-Somatic Index (GSI) for males and females in eastern Mediterranean. 


\section{Length at first maturity:}

The musky octopus is dioecious. Of the 156 females processed for maturity, 83 were mature while in 126 males that were processed for maturity, 95 individuals were mature (Table 2). The parameters for the fit of a logistic curve to the proportion mature by size and sex are given in Table 3, and shown in Fig. 6. The male were found to reach sexual maturity earlier than female individuals. The $50 \%$ sexual maturity level was reached at $7.2 \mathrm{~cm}$ CL for males and $7.4 \mathrm{~cm}$ CL mm for females.

Table 2: Mean Mantle length (cm) of Eledone moschata Lamarck, 1798 used in the minimum sexual maturity estimation.

\begin{tabular}{|c|c|c|c|c|}
\hline & \multicolumn{2}{|c|}{ Male } & \multicolumn{2}{|c|}{ Female } \\
\hline & Immature & Mature & Immature & Mature \\
\hline Mean & 6.3 & 8.9 & 6.7 & 8.8 \\
\hline Standard Error & 0.2 & 0.1 & 0.09 & 0.1 \\
\hline Minimum & 4.6 & 5.7 & 4.4 & 5.9 \\
\hline Maximum & 7.4 & 12.6 & 7.9 & 11.2 \\
\hline $\mathbf{N}$ & 31 & 95 & 73 & 83 \\
\hline
\end{tabular}

$\mathrm{N}$, number

Table 3: Minimum size $(-\mathrm{a} / \mathrm{b})$ of sexual maturity estimated from the logistic equation: $\mathrm{P}=\mathrm{e}^{\left(-a+\left(b^{*} \mathrm{~L}\right)\right)}$ / $\left(1+\mathrm{e}^{\left(-a+\left(b^{*} \mathrm{~L}\right)\right)}\right)$ for males and females of Eledone moschata Lamarck, 1798 (Plot is shown in Figure 6). (P: proportion mature, L: mantle length, $a$ and $b$ are the equation constants).

\begin{tabular}{lll}
\hline & Males & Females \\
\hline $\mathbf{a}$ & -13.395 & -20.952 \\
$\mathbf{b}$ & 1.873 & 2.674 \\
$\mathbf{- a} / \mathbf{b}$ & 7.15 & 7.84 \\
$\mathbf{r}$ & 0.942 & 0.97 \\
$\mathbf{N}$ & 126 & 156 \\
\hline
\end{tabular}

$\mathrm{N}$, number

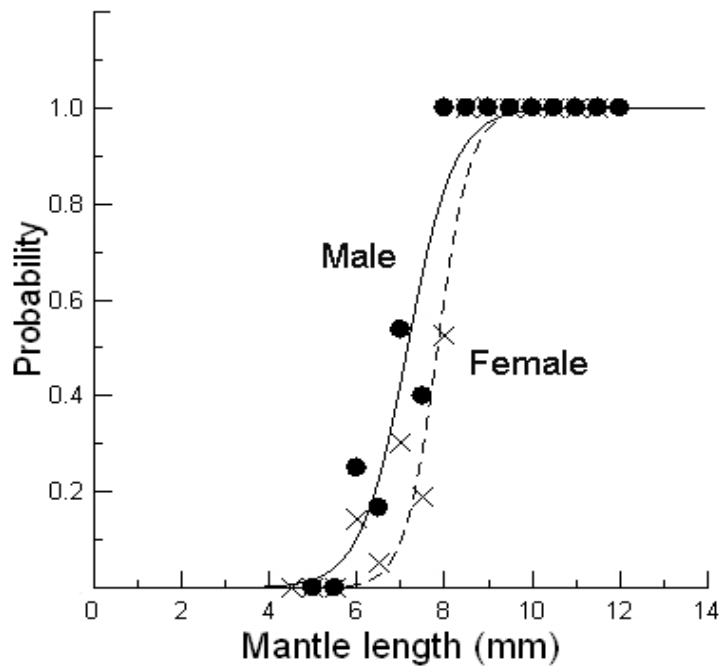

Fig. 6: Eledone moschata Lamarck, 1798, size at 50\% maturity for males and females in eastern Mediterranean (see Table 3 for equation). 


\section{Maturity stages:}

The occurrence of mature females and males throughout the period of study was examined. Fig. 7 illustrates the seasonal percentage composition of the maturity stages of both sexes. Males matured faster than females, as more males (about $60 \%$ ) were fully mature during spring than females, whereas only about $30 \%$ of the females were fully mature. It is clear that fully mature individuals were observed throughout the year for males and females.
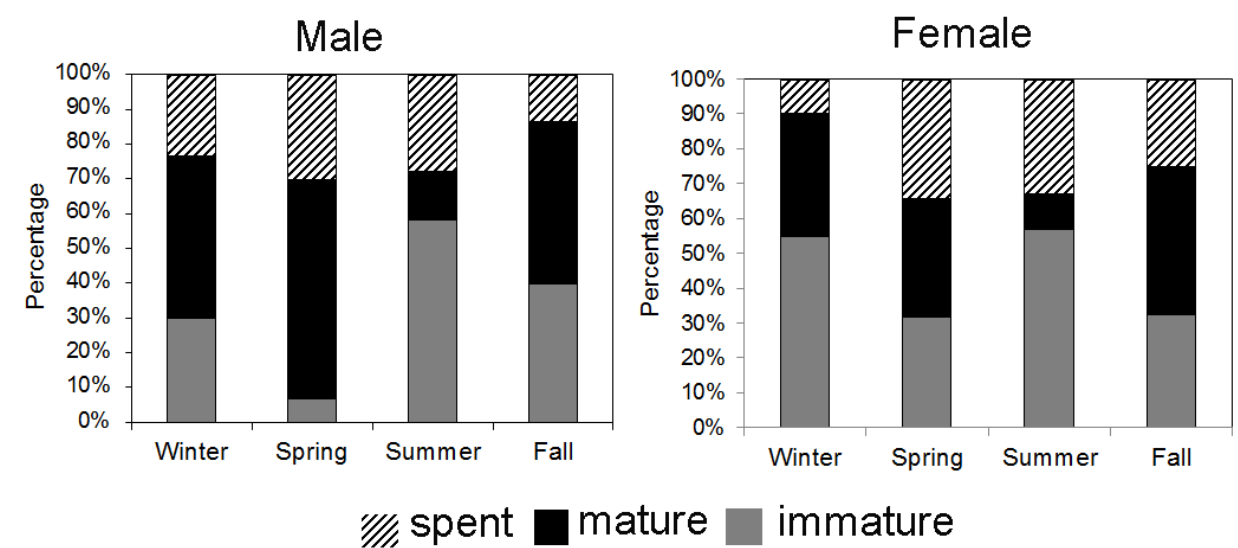

Fig.7: Eledone moschata Lamarck, 1798, maturity stages for male and female in different seasons in eastern Mediterranean.

\section{DISCUSSION}

The length-weight relationship showed that there is no significant difference between males and females although there was a slight difference between the two sexes. The females appeared to be slightly heavier than the males of the same length, as the slopes were 2.77 and 2.68 for females and males, respectively. Similar observation was recorded for a different cephalopod; Uroteuthis duvauceli in the Red Sea (Kilada and Riad, 2010) and in Thailand (Chotiyaputta, 1993). The difference in slope of the length-weight relationship may indicate the presence of sexual dimorphism, which is expressed as mature females having greater body weight compared with males of the same ML. The difference in weight between females and males may be related to the fact that the weight of the female gonads constitutes a greater proportion of the body weight in females than in males in larger sizes. This explains why the slopes of the length-weight relationship in males and females are closer to each other in small sizes, than the 2 regression lines diverge in larger animals.

Sex ratio revealed that the number of males and females varied in the 4 seasons although the difference was not significant statistically. The ratio was in favour of the females in the winter, spring and fall. In summer, on the other hand, males were slightly higher than females. The variation in the sex ratio appeared to be related to the reproduction biology of cephalopods. The samples of the current study were collected from deep waters in the Mediterranean. Similar to other cephalopod species such as Loligo gahi, mature adults of Eledone moschata would return to shallow waters to spawn (Hatfield et al., 1990), which explains the absence of more female specimens during the spawning season in summer. Similar observation was recorded in a different cephalopod; Uroteuthis duvauceli where the females became less than the males during the spawning season (Kilada and Riad, 2010). 
Length-frequency analysis revealed the presence of 2 modes in both males and females, with larger mean ML of each mode in males. It is assumed that each mode is equal to a year in the animal's life, and therefore the presence of 2 modes may indicate that the animal may live up to at least 2 years. The absence of smaller animals in the sample may be the reason for the absence of more modes in smaller sizes, which demonstrates that the animal may live more than 2 years. Age of cephalopods can be determined by counting the annual bands in thin sections of the stylets of Octopus pallidus (Leporati et al., 2008), in the upper and lower beaks, as in Octopus vulgaris (Hernández-López and Castro-Hernández, 2001), statoliths in squids (Hendrickson, 2004; Arkhipkin, 2005; Olyott et al., 2007). No available studies were found on the age of the musky octopus. However, in cephalopods in general, two years-life-span is common. In Octopus pallidus for example, the maximum recorded age for males was 589 days (Leporati et al., 2008). Also, for the Uroteuthis duvauceli, there were two modes in the length-frequency indicating two age classes (Kilada and Riad, 2010).

Present results revealed that number of eggs per gram of ovary declines with the increase in the ovary size. Similar observation was documented in the octopus Octopus dofleini in which the eggs number in a $1.2 \mathrm{~kg}$ ovary was about 100,000 (83 eggs per gram ovary) while in a $1.7 \mathrm{~kg}$ ovary the value was 35 eggs per gram ovary (Hartwick, 1983). This can be explained by the antagonistic effect of a simultaneous increase in the volume of yolk in the oocytes and their degeneration (Boyle and Chevis, 1992; Grubert and Wadley, 2000). Add to this, the number of eggs per gram ovary showed a significant variation in different seasons. The high rate was in winter, then declines significantly in spring and summer. The trend may be related to the spawning season.

In female Eledone moschata, the GSI values drop in spring and summer before it increases in fall. The lowest value was in summer which may indicate that the spawning occurred between summer and fall. This means that the spawning may take place between July and early November. This differs from what has been documented in the western Mediterranean in Tunisia where it was found that the spawning season of the musky octopus may extend between October to June (Ezzeddine-Najai, 1997). In the Adriatic Sea, Eledone moschata has an extended spawning season that started in the fall and ended in the following spring (Krstulovic-Sifner and Vrgoc, 2009). The variation in the timing of the spawning season of the same cephalopod species in different areas may be attributed to light and temperature (Richard, 1966; 1967).

The 50\% maturity level for Eledone moschata was reached in the male before the female. $\mathrm{L}_{50}$ in males and females were $7.2 \mathrm{~cm}$ CL and $7.4 \mathrm{~cm} \mathrm{CL}$, respectively. This pattern was documented in other areas where $L_{50}$ of the males was smaller than that of the females. For example, in the Gulf of Cadiz (south-western Spain) the $\mathrm{L}_{50}$ was $7.8 \mathrm{~cm}$ in males and $12.2 \mathrm{~cm}$ in females (Silva et al., 2004). Our findings may indicate that any management plan for this species should ensure that the mean size at capture is above $7.4 \mathrm{~cm}$ CL.

\section{REFERENCES}

Akyol, O., Sen, H., and Kinacigil, H.T. (2007). Reproductive biology of Eledone moschata (Cephalopoda: Octopodidae) in the Aegean Sea (Izmir Bay, Turkey). J. Mar. Bio. Ass., 87: 967 - 970.

Arkhipkin, A. (2005). Statoliths as "black boxes" (life recorders) in squid. Mar. Freshw. Res. 56: 573 - 583. 
Bakhayokho, M. (1983). Biology of the cuttlefish Sepia officinalis hierredda off the Senegal coast. FAO Fish.Tech.Pap./FAO Doc.Tech.Pêches/FAO Doc.Téc.Pesca., (231): 204 - 263.

Bhattacharya, C.G. (1967). A simple method of resolution of a distribution into Gaussian components. Biometrika, 23: 115 - 135.

Belcari, P. and Sbrana, M. (1999). Eledone moschata. In: G. Relini, J.A. Bertrand and A. Zamboni (eds.), Synthesis of the knowledge on bottom fishery resources in Central Mediterranean (Italy and Corsica). Biol. Mar. Medit., 6(1): 737 - 746.

Belcari, P.; Tserpes, G.; Gonzalez, M.; Lefkaditou, E.; Marceta, B.; Piccinetti Manfrin, G. and Souplet, A. (2002). Distribution and abundance of Eledone moschata (Lamarck, 1798) and Eledone moschata (Lamarck, 1798) (Cephalopoda: Octopoda) in the Mediterranean Sea. Sci. Mar., 66 (2): 143- 155.

Boyle, P.R. and Chevis, D. (1992). Egg development in the Eledone cirrhosa. J. Zool., 227: 623 -638.

Casali, P.; Manfrin Piccinetti, G. and Soro, S. (1998). Distribuzione di cephalopodi in alto e medio Adriatico. Biol. Mar.Medit., 5: 307 - 317.

Chotiyaputta, C. (1993). A survey on diversity and distribution of juvenile squids in the inner and western Gulf of Thailand. Thai. Mar. Fish. Res. Bull., 4: 19 - 36.

Ezzeddine- Najai, S. (1997). Sexual maturation in Eledone moschata (Cephalopoda, Octopoda) from the gulf of Gabes (Tunisia, eastern Mediterranean). Vie Milieu, 47: 69 - 76.

FAO (2011). Review of the state of world marine fishery resources. Rome: FAO. 354 pp.

Gabr, H.R. and Riad, R. (2008). Reproductive biology and morphometric characters of the squid Loligo forbesi (Cephalopoda: Loliginidae) in the Suez Bay, Red Sea, Egypt. Egypt J. Aquat. Biol. Fish., 12: 59 - 73.

Gayanilo, F.C., Jr., Sparre, P. and Pauly, D. (2005). FISAT II: FAOICLARM stock assessment tool. Rome: ICLARM. 99 pp.

Grubert, M.A. and Wadley, V.A. (2000). Sexual maturity and fecundity of Octopus maorum in Southeast Tasmania .Bull. Mar. Sci., 66: 131 - 142.

Guerra, A. (1981). Spatial distribution pattern of Octopus vulgaris. J. Zool. Lond. 195: 133 - 146.

Hartwick, E.B. (1983). Octopus dofleini. Pages 277-291. In Boyle, P.R., (ed) Cephalopod life cycles, vol. 1. Academic Press, London.

Hatanaka, H. (1979). Studies on the fisheries biology of common octopus off the northwest coast of Africa. Far Seas Fish. Res. Lab. Bull., 17: 13 - 124.

Hatfield, E.M.C., Rodhouse, P.G. and Porebski, J. (1990). Demography and distribution of the Patagonian squid (Loligo gahi d'Orbigny) during the austral winter. J. Conseil Intern. Expl. Mer, 46: 306 - 312.

Hernández-López, J.L and Castro-Hernández, J.J. (2001). Age determined from the daily deposition of concentric rings on common octopus (Octopus vulgaris) beaks. Fish Bull. 99: 679 - 684.

Hendrickson, L. (2004). Population biology of northern short fin squid (Illex illecebrosus) in the northwest Atlantic Ocean and initial documentation of a spawning area. ICES J. Mar. Sci., 61: 252-266.

Kilada, R. and Riad, R. (2010). Seasonal Reproduction Biology of Uroteuthis duvauceli (Cephalopoda: Loliginidae) in Northern Red Sea, Egypt. J. Shellfish Res., 29: 781 - 791. 
Krstulovic Sifner, S.K. and Vrgoc, N. (2009). Reproductive cycle and sexual maturation of the musky octopus Eledone moschata (Cephalopoda: Octopodidae) in the northern and central Adriatic Sea. Scientia Marina, 73: $439-447$.

Krstulovic Sifner, K. S.; dadić, V. and Vrgoč, N. (2004). GIS presentation of distribution of two Eledonid species in the Adriatic Sea. In: D. kereković (ed.), GIS in research and practice, pp. 124- 131. Hrvatski informatički Zbor, Zagreb.

Krstulovic Sifner, K.S.; Lefkaditou, E.; Ungaro, N.; Ceriola, L. ; Osmani, K.; Kavadas, S. and Vrgoč, N. ( 2005). Composition and distribution of the Cephalopod fauna in the Eastern Adriatic and Eastern Lonian Sea. Isr. J. Zool., 51: 315 - 330.

Lefkaditou, E., A. Siapatis and Papaconstantinou, C. (1998). Seasonal and spatial changes in the abundance and distribution of Eledone moschata (Cephalopoda: Octopoda), in the South Aegean Sea (Eastern Mediterranean). ICES CM, Copenhagen.

Lefkaditou, E.; Leondarakis, P.; Papaconstantinou, P.C. and Tsangridis, A. (2001). Eledonids exploited in the Thracian Sea: preliminary analysis of stock structure based on trawlers landings. Rapp. Comm..Int. Mer. Médit., 36: 294 294.

Leporati, S.C., Pecl G.T. and Semmens, J.M. (2008). Reproductive status of Octopus pallidus, and its relationship to age and size. Mar. Biol., 155: 375 - 385.

Mangold, K. (1983). Eledone moschata. In: Boyle, P.R. (ed.), Cephalopod life cycles. 1:387- 400, Academic Press, London.

Mangold- Wirz, K. (1963). Biologie des Cephalopods bentiques et nectonique de la Mer Catalane. Vie Milieu, 13: 83- 91.

McCullagh, P. and Nelder, J.A. (1989). Generalized linear models. Chapman \& Hall, London.

Olyott, L., Sauer, W. and Booth A. (2007). Spatial patterns in the biology of the chokka squid, Loligo reynaudii on the Agulhas Bank, South Africa. Rev. Fish Biol. Fish. 17: 159 - 172.

Ozyurt, G., Duysak, O., Akamca E., and Tureli C. (2006). Seasonal changes of fatty acids of cuttlefish Sepia officinalis L. (Mollusca: Cephalopoda) in the north eastern Mediterranean sea. Food Chem., 95: 382 - 385.

Piccinetti, C. and Jukić, S. (1988). Data on the demersal resources of the upper and middle Adriatic. FAO Fish. Rep., 394: 172 - 173.

Pierce, G.J., Boyle, P.R., Hastie, L.C. and Key L. (1994). The life history of Loligo forbesii (Cephalopoda: Loliginidae) in Scottish waters. In: P. R. Boyle \& G. J. Pierce, editors. Fishery Biology of Northeast Atlantic Squid. Fish Res., 21:1741.

Pipitone, C., F. Badalamenti; Anna, G. D' and Patti, B. (2000). Fish biomass increase after a four- year trawl ban in the Gulf of Castellammare (NW Sicily, Mediterranean Sea). Fish. Res., 48: 23 - 30.

Poveda, O.H., Colin-Flores R.F. and Rosas C. (2009). Gonad development during the early life of Octopus maya (Mollusca: Cephalopoda). Biol. Bull. Mar. Biol. Lab. Woods Hole, 216: 94 - 102.

Quetglas, A.; Carbonell, A. and Sanchez, P. (2000). Demersal continental shell and upper slope cephalopod assemblages from the Balearic Sea (NW Mediterranean). Biological aspects of some deep- sea species. Estuar. Coast. Shelf Sci., 50: 739 - 749. 
Richard, A. (1966). Action de la temperature sur l' evolution genital de Sepia officinalis L.C.r. hebd. Seanc. Acad. Sci., Paris (Serie D) 263: 1998 - 2001.

Richard, A. (1967). Role de la photoperiode dans le determinisme de la maturation genital femelle du Cephalopode de Sepia officinalis L.C.r. hebd. Seanc. Acad. Sci., Paris (Serie D) 264: 1315 - 1318.

Roper, C.F.E.; Sweeney, M.J. and Nauen, C.E. (1984). FAO species catalogue. Vol. 3. Cephalopods of the world. An annotated and illustrated catalogue of species of interest to fisheries. FAO Fish. Synop. No. 125 ( 3), 277pp.

Salman, A., Katagan, T. and Gucu, A.C. (2000). The distribution and fishing of two Mediterranean Eledone moschata spp. (Octopoda: Cephalopoda) in the Aegean Sea. Turk. J. Zool., 24: 165 - 171.

Silva, L.; Ramos, F. and Sobrino, I. (2004). Reproductive biology of Eledone moschata (Cephalopoda: Octopodidae) in the Gulf of Cádiz (south- western Spain, ICES Division IXa). J. Mar. Biol. Ass. U.K., 84: 1221 - 1226.

Soro, S. and Piccinetti Manfrin, G. (1989). Biologia e pesca di Cefalopodi in Adriatico. Nova Thalassia, 10: 493 - 498.

Teissier, G. (1948). La relation d'allome' trie: sa signification statistique et biologique. Biometrics, 4: 14 - 53.

Whitaker, J.D., Delancy, L.B. and Jenkins, J.E. (1991). Aspects of the biology and fishery potential for Octopus vulgaris off the coast of South Carolina. Bull. Mar. Sci., 49: 482 - 493.

\section{ARABIC SUMMARY}

بيولوجية التكاثر للنوع Eledone moschata (رأسقدميات ـ أخطبوطات) في شرق البحر المتوسط ، مصر

$$
\begin{aligned}
& \text { رفيق رياض (') رؤوف قلادة (r) }
\end{aligned}
$$

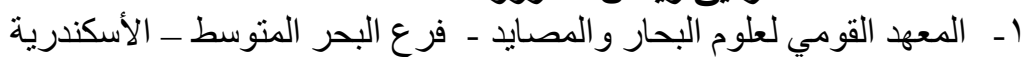

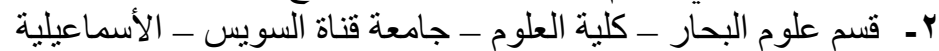

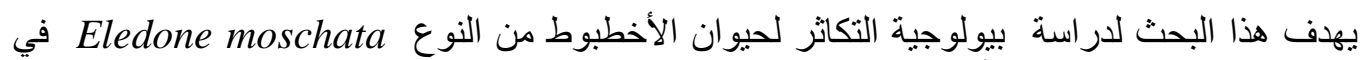

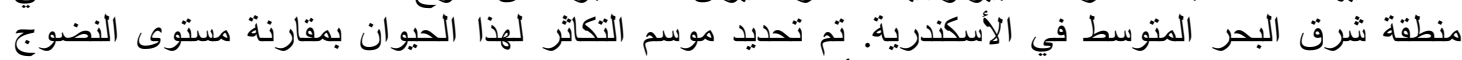

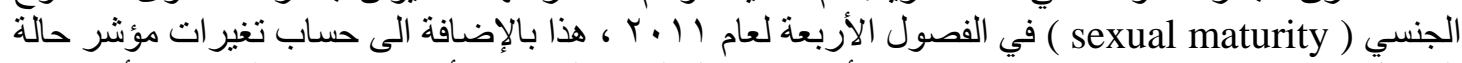
المناسل (gonado somatic index) في الأربعة فصول لنفس العام وقد أوضحت هذه الحساب الحسابات أن درجة

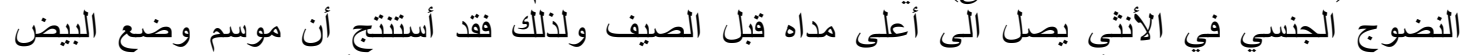

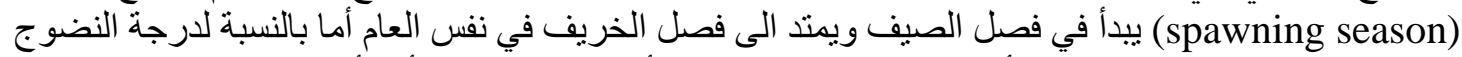

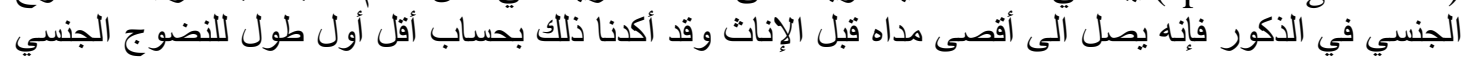

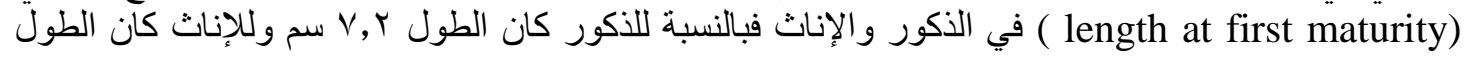

وَّم أيضا في هذه الدراسة تحليل التوزيع الطولي ( length- frequency ) لتقدير عمر الحيوان لأول

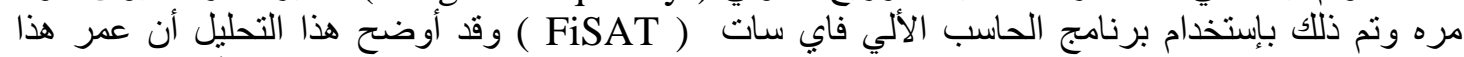

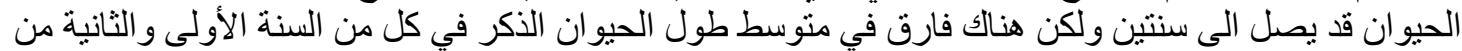

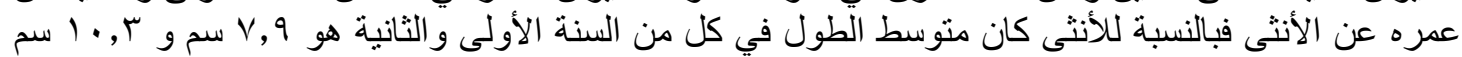

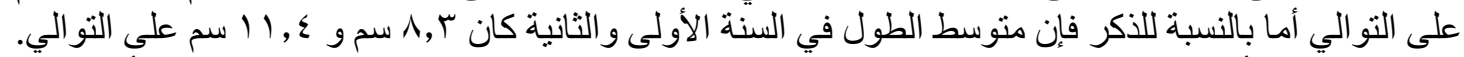

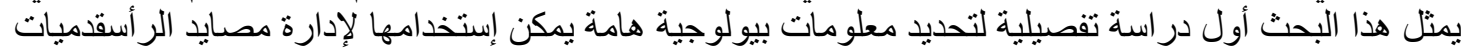

